\title{
Study Added of Waste Chicken Egg Shell in Soils
}

\author{
Irwan Lie Keng Wong \\ Universitas Kristen Indonesia Paulus/Civil Engineering, Makassar, South Sulawesi, Indonesia
}

\begin{abstract}
Soil is the foundation of structure or construction that will receive the load transfer through to foundation. If the soil has a carrying capacity of small and cannot withstand the load transfer can result in the failure of construction. If the soil has a carrying capacity of small ground it is necessary to stabilize or improve the soil so that an increase in the carrying capacity of the land so that it can be used for construction. One material is commonly used for soil stabilization with the addition of lime. Waste chicken egg shell is waste that is still rarely used, the results of research [1], states that composition egg shell broadly consists of water $(1,6 \%)$ and dry material $(98,4 \%)$. The total dry ingredients are there, in shell eggs contained mineral elements $(95,1 \%)$ and protein $(3,3 \%)$. Based on the existing mineral composition, then the egg shells are composed of crystalline $\mathrm{CaCO}_{3}(98,43 \%), \mathrm{MgCO}_{3}(0,84 \%)$ and $\mathrm{Ca}_{3}\left(\mathrm{PO}_{4}\right)_{2}(0,75 \%)$. This research was done by adding powdered chicken egg shell waste in clay with a composition of $5 \%, 7,5 \%, 10 \%$ and $14 \%$ with physical properties test and soil compaction test.
\end{abstract}

This research is an experimental study dan the results showed classification of soil with system USCS (Unified Soil Classification System) shows the percentage of grains of soil sieve No. 200 amounted to $60,24 \%$ (> 50\%), then USCS ground based system can be classified as fine-grained soil, liquid limit is $31,92 \%$ and plasticity index is 5,44 so that the soil is classified as silt organic and clay organic with low plasticity (OL). Unit weight dry $\left(\gamma_{\text {dry }}\right)$ value in the addition of $10 \%$ waste chicken egg shell has increased a maximum of $1.58 \mathrm{gr} / \mathrm{cm}^{3}$ into $1,630 \mathrm{gr} / \mathrm{cm}^{3}$ at 14 days of aging (increase occurred at $3,164 \%)$. Water Content Optimun $\left(\mathrm{w}_{\mathrm{opt}}\right)$ in the addition of $10 \%$ waste chicken egg shell has decreased a maximum of $22,18 \%$ into $20,33 \%$ at 21 days of aging (decrease occurred at $1,85 \%$ ).

\section{Introduction}

Land is an essential element in the development of the construction as a beachhead foundation that bears the entire burden of the construction that was built on it. If bearing capacity of soil is low and soil properties are sensitive to water maybe cause damage to the construction, examples of the damage that may occur landslip, cracks in the pavement (cracking), the structure of plates uplifted, the soil expands, etc.

Soil stabilization can be done to increase the carrying capacity of the land The first method is the mechanical stabilization for example, mixing several types of soils with the aim of producing well graded soil, the installation of other materials as reinforcement on the ground, use of geotextiles as well as the improvement of the soil surface with a drainage system. The second method is soil improvement with the addition of chemical stabilization of added materials (additive) to the soil to improve soil physical properties, such as strength, texture, workability and plasticity. Materials that can be used as an added ingredient in the improvement of the soil include lime, portland cement, asphalt (bitumen), fly ash, etc.

Soil stability is mixing the soil with certain materials to improve the engineering properties of soil stabilization. Process covering soil mixing with other soil or added material to obtain the desired gradation so that the engineering properties of the soil such as: strong support, compressibility, permeability, potential for development and sensitivity becomes better [1].

\section{Chiken eggshell}

Egg shell is the outermost part of the egg that serves to give protection to the component of the egg content from damage,either physically, chemically and micro- biologically, the rest of the hatchery is meant here is everything waste generated from industries such hatching eggs that did not hatch (sterile), eggshell of chicks that have hatched and eggshells in it still contains the embryo dead. When observed through a microscope, it can be seen that the eggshell is composed of four layers, namely: 


\subsection{Cuticle layer.}

Cuticle is a transparent layer of proteins that coat the surface of the eggshell. This layer lining the pores in the eggshell but nature can still be passed gas so that the discharge of water vapor and $\mathrm{CO}_{2}$ gas can still occur.

\subsection{Foam layer.}

This layer is the biggest part of the skin layer of the egg. This layer consist of protein and limestone layers consisting of calcium carbonat, calcium phosphate, magnesium carbonat and magnesium phosphate.

\subsection{Mammillary layer.}

This layer is the third layer of the egg shell consists of a cone-shaped layers with a round or oval cross-section. This layer is very thin and consists of woven protein and minerals.

\subsection{Membrane layer.}

This is part of the deepest layer of the egg shell. Composed of two layers of the membrane that envelops the entire contents of the egg.

Based on this research, chicken egg shell powder contains calcium of $401 \pm 7.2$ grams or about $39 \%$ of calcium, in the form of calcium carbonate. There is also a strontium at $372 \pm$ $161 \mu \mathrm{g}$, toxic substances such as $\mathrm{Pb}, \mathrm{Al}, \mathrm{Cd}$, and $\mathrm{Hg}$ in small quantities, as well as $\mathrm{V}, \mathrm{B}, \mathrm{Fe}, \mathrm{Zn}, \mathrm{P}, \mathrm{Mg}, \mathrm{N}, \mathrm{F}, \mathrm{Se}, \mathrm{Cu}$, and $\mathrm{Cr}[2]$.

The composition of egg shell broadly consists of water $(1,6 \%)$ and dry matter $(98,4 \%)$. The total dry ingredients are there, in shell eggs contained mineral elements $(95,1 \%)$ and protein $(3,3 \%)$ [3], the existing mineral composition, then the egg shells are composed of crystal $\mathrm{CaCO}_{3}(98,43 \%), \mathrm{MgCO}_{3}$ $(0,84 \%)$ and $\mathrm{Ca}_{3}\left(\mathrm{PO}_{4}\right)_{2}(0,75 \%)$.

\section{Calcium carbonate ( $\mathrm{CaCO})$}

Calsium carbonate is the calcium salts contained in chalk, limestone, marble and is a major component contained in egg shells [4]. Calcium carbonate powder form, white, odorless, tasteless, stable in air. Partically insoluble in water, solubility in water increases with little ammonium salts or carbon dioxide. Insoluble in nitric acid to form gas bubles [5].

One of the chemical properties of calcium carbinate that can neutralized the acid. The use of calcium carbonate in the pharmaceutical field is as an antacid because of its ability to neutralize the acid but calcium carbonate can cause constipation.

If calcium carbonate is heated to a temperature of $900^{\circ} \mathrm{C}$, the calcium carbonate will form kalsium oxide $(\mathrm{CaO})$ due to release of carbon dioxide $\left(\mathrm{CO}_{2}\right)$, The reaction can be written as follow:

$$
\mathrm{CaCO}_{3} \underset{\mathrm{T}=900^{\circ} \mathrm{C}}{\longrightarrow} \mathrm{CaO}+\mathrm{CO}_{2}
$$

$\mathrm{CO}_{2}$ is an exhaust gas which can have a negative impact on human health, therefore living soil stabilization with lime (quicklime) or calcium oxide $(\mathrm{CaO})$ which is generally obtained from the above reaction can have a negative impact on the environment.

\section{Soil physical properties test}

\subsection{Water content (w).}

Water content (Moisture content) is the ratio between weight of water to weight of the soil grains. The water content is percentage of water a material that can be expressed by wet weight (wet basis) or based on the dry weight (dry basis). The water content of the wet weight has a theoretical maximum limit of 100 percent, while the water content by dry weight can be more than 100 percent [6].

\subsection{Specific gravity (G).}

Specific gravity is the ratio of the density of a substance to the density of a reference substance; equivalently, it is the ratio of the mass of a substance to the mass of a reference substance for the same given volume. Apparent specific gravity is the ratio of the weight of a volume of the substance to the weight of an equal volume of the reference substance. [7]

\subsection{Attegberg limit.}

Atterberg limits introduced by Albert Atterberg in 1911 with the aim of fine-grained soil to classify and determine the nature of the soil property index. Atterberg limits comprise the liquid limit, plastic limit, and shrinkage limit. [8]

Fine grained soils usually have plastic properties. The plastic properties of the soil's ability to adjust the shape change of the ground after mixed with water at a fixed volume. The land will be a liquid, plastic, semi-solid or solid depending on the amount of water that is mixed in the soil. Atterberg limits show the shape of the solid ground to become viscous fluids according to their water content. Atterberg limits of test parameters will be obtained liquid limit, plastic limit, sticky limit and limit cohesion which is the state of the soil consistency. Atterberg boundaries can be seen in the following Table 1 below:

Table 1. Plasticity limit of soils

\begin{tabular}{|c|l|l|l|}
\hline PL(\%) & \multicolumn{1}{|c|}{ Character } & Type of soils & \multicolumn{1}{|c|}{ Cohesif } \\
\hline 0 & Non plastic & Sand & Non cohesif \\
\hline$<7$ & Low plasticity & Silt & Cohesion partly \\
\hline $7-17$ & Medium plasticity & Clayed silt & Cohesif \\
\hline$>17$ & High plasticity & Clay & Cohesif \\
\hline
\end{tabular}

Liquid limit (LL) is the water content of soil for the values above, the soil will behave as a viscous liquid (the boundary between the liquid state and a plastic state), which is the upper limit of the plastic area.

Plastic limit (PL) is the water content to values below, the ground is no longer influential as the plastic material. Soil will be a plastic material in a water content ranging between LL and PL. This range is called the plasticity index.

Plasticity Index (PI) is an interval of water content, the soil still is plastic. Therefore, the plastic index indicates the nature of the soil keplastisitas. If the soil has a water content interval small plastic area, then this state is called invitation 
thin soil. In contrast, $\mathrm{jka}$ soil water content interval area has a large plastic called peat. Plasticity index value can be calculated with the following equation:

$$
\mathrm{IP}=\mathrm{LL}-\mathrm{PL}
$$

Restrictions on plastic index, the nature, kinds of soil and cohesion provided by Atterberg contained in the following Figure 1:

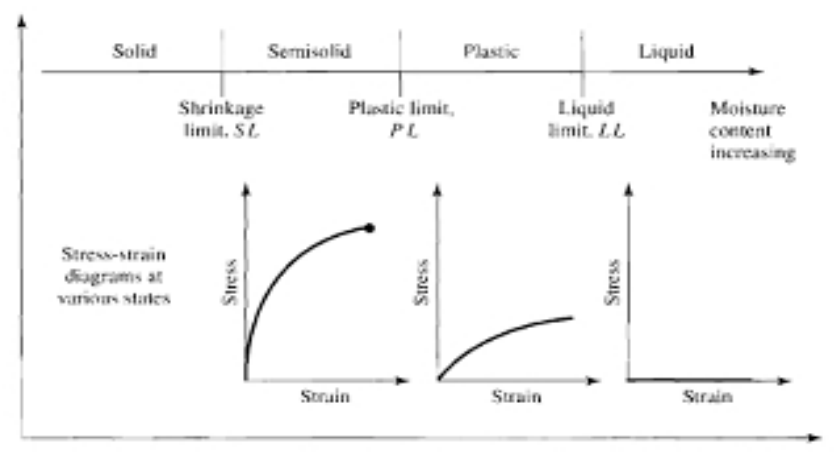

Figure 1. Attegberg limits

Shrinkage Limit (SL). Condition water content at the position between the semi-solid and solid areas, namely the percentage of moisture content where further reduction of water content does not lead to changes in the volume of soil is called Limit Losses.

$$
\mathrm{SL}=\left(\mathrm{V}_{0} /\left(\mathrm{W}_{0}-1 / \mathrm{Gs}\right)\right) \times 100 \%
$$

where :

$\mathrm{SL}=$ Shrinkage limit

$\mathrm{V}_{0}=$ Volume of specimen dry

$\mathrm{W}_{0}=$ Weight of specimen dry

$\mathrm{Gs}=$ Specific gravity

\section{Mechanical analysis of soil}

Gradation of soils. Mechanical analysis is the determination of the size range of particles present in a soil, expressed as a percentage of the total dry weight. Two methods are generally used to find the particle size distribution of soil:

Sieve analysis - for particle sizes larger than $0,075 \mathrm{~mm}$ in diameter.

Hydrometer analysis - for particle sizes smaller than $0,075 \mathrm{~mm}$ in diameter.

The basic principle of sieve analysis and hydrometer analysis are briefly described in the following two section.

Modified proctor test. Modified Proctor compaction test is a laboratory method to determine the optimal experimental moisture content where in a particular type of soil will be the most solid and achieve maximum dry density. The term proctor is to honor RR Proctor, who in 1933 showed that the dry density for a given compaction effort depends on the amount of groundwater during soil compaction and the original tests often referred to as a standard proctor compaction test [9]. Laboratory tests generally consist of soil compaction on water levels known to the cylinder mold dimensions using the standard amount of compaction effort is controlled. The soil is usually compacted into molds with a certain amount of the same layer, each received a blow from a hammer-weighted standard at a certain height. The process is then repeated for a range of water content and dry density determined for each. Graphic relationship of the dry density of the water content is then plotted to form a curve compaction. Finally maximum dry density obtained from the cusp of the curve compaction and moisture content are appropriate, also known as the optimum moisture content.

The formula used in the calculation modified proctor compaction as follows:

$$
\mathrm{ZAV}=\mathrm{Gs} /(1+(\mathrm{Gs}+\mathrm{w}) / 80)
$$

$$
\gamma=(\text { weight of wet soil / (volume mold) }
$$

$$
\gamma_{\mathrm{d}}=\mathrm{V} /(1+\mathrm{w})
$$

where ;

$$
\begin{array}{ll}
\text { Z.A.V } & =\text { zero void water } \\
\mathrm{w} & =\text { moisture content } \\
\mathrm{Gs} & =\text { specific gravity } \\
\gamma_{\mathrm{d}} & =\text { Unit weight } \mathrm{dry}\left(\mathrm{g} / \mathrm{cm}^{3}\right) \\
\gamma & =\text { Unit weight }\left(\mathrm{g} / \mathrm{cm}^{3}\right)
\end{array}
$$

\subsection{Soil sampling test}

Soils sampling sites taken in district Gowa, Sunggu- minasa, Subdistrict Pallangga, Poros Limbung.street in South Sulawesi Province, country Indonesia.

Testing was conducted in laboratory test soils mechanics Universitas Atmajaya Makassar.

\subsection{Flow diagram}

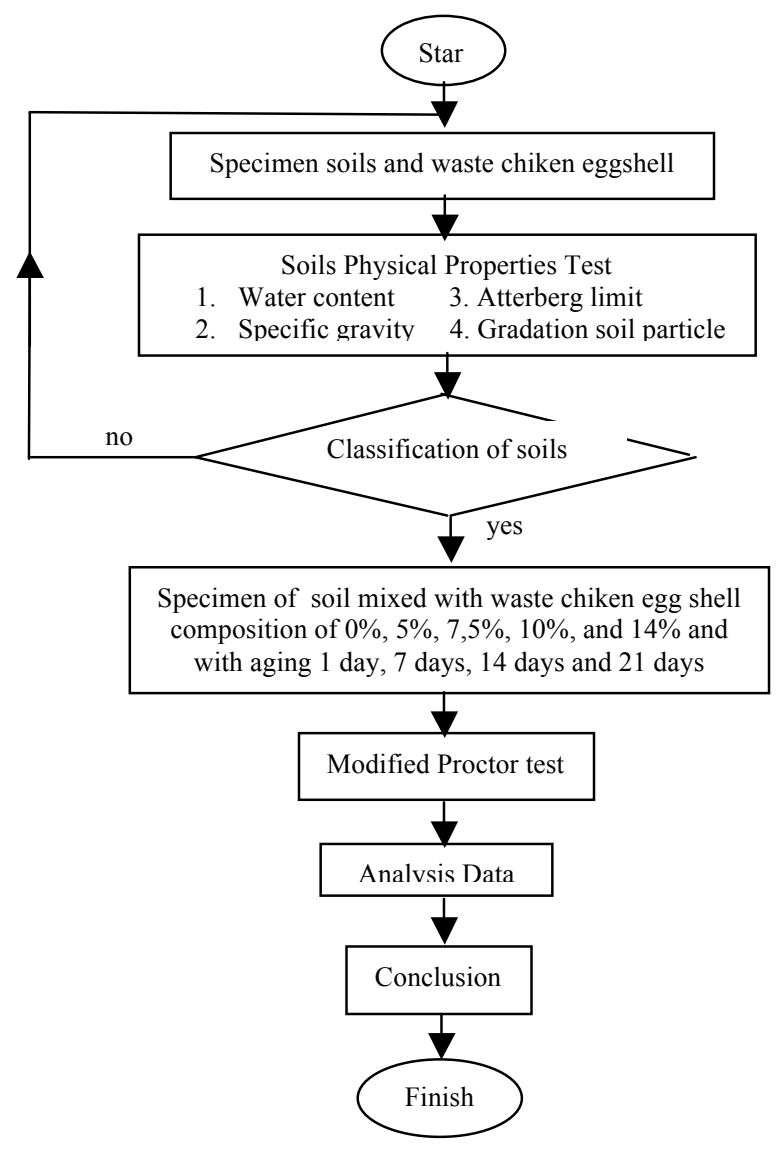

Figure 2. Flow diagram

Above diagram is shown in the following Figure 2: 


\section{Methodology}

Types of research. Research was an experimental study, to make trial samples and then test in soil mechanics laboratory. Samples for testing are made as many as 85 samples, consisting of soil samples no mixture is 5 sample, sample soils with the addition of $5 \%, 7.5 \%, 10 \%$ and $14 \%$ respectively of 20 samples consisting of 5 samples for soaked 1 day, 5 samples for soaked 7 days, 5 samples for soaked of 14 days and 5 samples for soaked of 21 days.

Standard of Reference. Table 2 shows the reference laboratory test

Table 2. Standard of reference

\begin{tabular}{|l|l|}
\hline \multicolumn{1}{|c|}{ Test } & \multicolumn{1}{c|}{ Reference } \\
\hline Water Content & ASTM D-2216-98 \\
\hline Unit Weight & ASTM D-854-02 \\
\hline Sieve Analysis & ASTM D 1140 \\
\hline Liquit Limit & ASTM D-4318-00 \\
\hline Plastis Limit & ASTM D-4318-00 \\
\hline Modified Proctor & ASTM D-698 \\
\hline
\end{tabular}

\subsection{Analysis data}

Soil physical mechanical properties. Soil Physical Properties Test results are shown in Table 3:

According to the Unified Soil Clasification System (USCS), including fine-grained soil, this is expressed by percent through sieve 200 more than $50 \%$. Liquid limit values obtained less than $50 \%$ causes the soil has a low plasticity. From the results of soil classification by USCS then district Gowa, Sunggu-minasa, Subdistrict Pallangga, Poros Limbung.street in South Sulawesi Province belonging to the types of silt organic and clay organic with low plasticity (OL).

Table 3. Testing physical and mechanical properties of soils

\begin{tabular}{|c|l|c|}
\hline No & \multicolumn{1}{|c|}{ Soils test } & Value \\
\hline 1 & Water content $(\mathrm{w})$ & $27,61 \%$ \\
\hline 2 & Unit weight $(\gamma)$ & 2,475 \\
\hline 3 & Liquid Limit $(\mathrm{LL})$ & $31,92 \%$ \\
\hline 4 & Plastic Limit $(\mathrm{PL})$ & $26,48 \%$ \\
\hline 5 & Index Plasticity $(\mathrm{IP})$ & $5,44 \%$ \\
\hline 6 & Shrinkage Limit $(\mathrm{SL})$ & $19,44 \%$ \\
\hline 7 & Percent sieve 200 & $60,24 \%$ \\
\hline 8 & Unit weight dry $(\gamma \mathrm{d})$ & $1,58 \mathrm{gr} / \mathrm{cm}^{3}$ \\
\hline 9 & Water content optimum $\left(\mathrm{w}_{\text {opt }}\right)$ & $20,33 \%$ \\
\hline
\end{tabular}

Testing chemical properties of waste chiken eggs shell. Testing chemical properties of waste chiken eggs shell results are shown in Table 4:

Chemical test results show that waste chiken eggs shell contains Calcium $(\mathrm{Ca})$ is $37,30 \%$ and Carbonate $\left(\mathrm{CO}_{3}\right)$ is $58,0 \%$ which is large around $95,30 \%$.

Modified proctor test. Modified Proctor test with the original soil, water content optimum $\left(\mathrm{w}_{\mathrm{opt}}\right)$ is $20,33 \%$ and unit weigth of dry is $1,58 \mathrm{gr} / \mathrm{cm}^{3}$. Result modified proctor test in the addition of a waste chicken egg shell with aging 1 day, 7 days, 14 days and 21 days are shown in Table 5 to 8 below:
The test results of modified proctor test showed the addition of waste chicken eggs as much as $10 \%$ obtained value unit weight dry maximum where the aging 1 day obtained is $1,612 \mathrm{gr} / \mathrm{cm}^{3}$, aging 7 days obtained is 1,618 $\mathrm{gr} / \mathrm{cm}^{3}$, aging 14 days was obtained $1,630 \mathrm{gr} / \mathrm{cm}^{3}$ and 21 days of aging was obtained $1,625 \mathrm{gr} / \mathrm{cm}^{3}$. Unit weight dry value in the addition of $10 \%$ waste chicken egg shell has increased a maximum of $1.58 \mathrm{gr} / \mathrm{cm}^{3}$ into $1,630 \mathrm{gr} / \mathrm{cm}^{3}$ at 14 days of aging (increase occurred at 3,164\%).

Graph addition of waste chicken egg shell to the value of the unit weight dry shown in Figure 3 below.

Figure 3 shows the maximum value of unit weight dry of $10 \%$ occurred on the addition of waste chicken egg shell on curing 14 days and the addition of up to $14 \%$ showed a decline of $1,630 \mathrm{gr} / \mathrm{cm}^{3}$ be $1,628 \mathrm{gr} / \mathrm{cm}^{3}$.

Table 4. The absolute and relative weight of the mineral constituent of egg shell

\begin{tabular}{|l|c|c|}
\hline Mineral & $\begin{array}{c}\text { \% of the total } \\
\text { weight }\end{array}$ & $\begin{array}{c}\mathrm{g} / \text { total } \\
\text { weight }\end{array}$ \\
\hline Calcium $(\mathrm{Ca})$ & 37,30 & 2,30 \\
Magnesium $(\mathrm{Mg})$ & 0,38 & 0,02 \\
Phosphorus $(\mathrm{P})$ & 0,35 & 0,02 \\
Carbonate $\left(\mathrm{CO}_{3}\right)$ & 58,00 & 3,50 \\
Manganese $(\mathrm{Mn})$ & 7,00 & $\mathrm{ppm}$ \\
\hline
\end{tabular}

Source [3]

Table 5. Result Modified Proctor test with aging 1 day

\begin{tabular}{|c|c|c|c|}
\hline No & $\begin{array}{c}\text { Waste } \\
\text { chiken eggs } \\
\text { shell }\end{array}$ & $\begin{array}{c}\text { Unit weight } \\
\text { dry }\left(\mathrm{gr} / \mathrm{cm}^{3}\right)\end{array}$ & $\begin{array}{c}\text { Optimun } \\
\text { Moistuire } \\
\text { Content }(\%)\end{array}$ \\
\hline 1. & $5 \%$ & 1,599 & 16,46 \\
\hline 2. & $7,5 \%$ & 1,605 & 17,29 \\
\hline 3. & $10 \%$ & 1,612 & 17,36 \\
\hline 4. & $14 \%$ & 1,610 & 17,31 \\
\hline
\end{tabular}

Table 6. Result Modified Proctor test with aging 7 day

\begin{tabular}{|c|c|c|c|}
\hline No & $\begin{array}{c}\text { Waste } \\
\text { chiken eggs } \\
\text { shell }\end{array}$ & $\begin{array}{c}\text { Unit weight } \\
\text { dry }\left(\mathrm{gr} / \mathrm{cm}^{3}\right)\end{array}$ & $\begin{array}{c}\text { Optimun } \\
\text { Moistuire Content } \\
(\%)\end{array}$ \\
\hline 1. & $5 \%$ & 1,602 & 17,54 \\
\hline 2. & $7,5 \%$ & 1,609 & 18,96 \\
\hline 3. & $10 \%$ & 1,618 & 21,46 \\
\hline 4. & $14 \%$ & 1,615 & 19,61 \\
\hline
\end{tabular}

Table 7. Result Modified Proctor test with aging 14 day

\begin{tabular}{|c|c|c|c|}
\hline No & $\begin{array}{c}\text { Waste } \\
\text { chiken eggs } \\
\text { shell }\end{array}$ & $\begin{array}{c}\text { Unit weight } \\
\text { dry }\left(\mathrm{gr} / \mathrm{cm}^{3}\right)\end{array}$ & $\begin{array}{c}\text { Optimun } \\
\text { Moistuire Content } \\
(\%)\end{array}$ \\
\hline 1. & $5 \%$ & 1,622 & 19,55 \\
\hline 2. & $7,5 \%$ & 1,625 & 20,48 \\
\hline 3. & $10 \%$ & 1,630 & 22,08 \\
\hline 4. & $14 \%$ & 1,628 & 20,13 \\
\hline
\end{tabular}

Table 8. Result Modified Proctor test with aging 21 day

\begin{tabular}{|l|l|l|l|}
\hline No & Waste & Unit weight & Optimun \\
\hline
\end{tabular}




\begin{tabular}{|c|c|c|c|}
\hline & $\begin{array}{c}\text { chiken eggs } \\
\text { shell }\end{array}$ & dry $\left(\mathrm{gr} / \mathrm{cm}^{3}\right)$ & $\begin{array}{c}\text { Moistuire Content } \\
(\%)\end{array}$ \\
\hline 1. & $5 \%$ & 1,618 & 19,10 \\
\hline 2. & $7,5 \%$ & 1,620 & 20,20 \\
\hline 3. & $10 \%$ & 1,625 & 22,18 \\
\hline 4. & $14 \%$ & 1,619 & 20,10 \\
\hline
\end{tabular}

\section{Unit Weight Dry vs Waste Chiken Egg Shell}

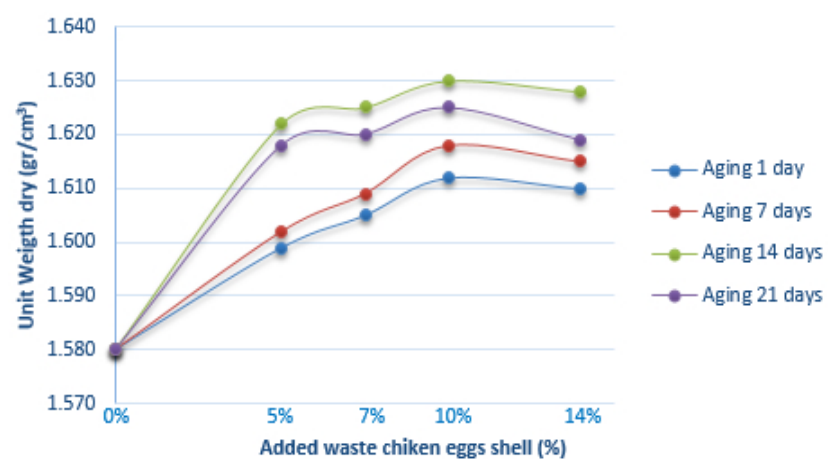

Figure 3. Unit weight dry vs waste chiken egg shell

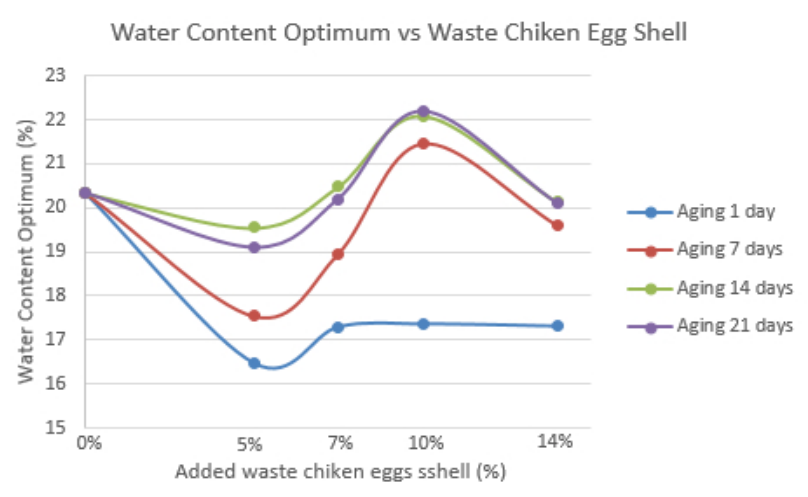

Figure 4. Water content optimun vs waste chiken egg shell

Graph addition of waste chicken egg shell to the value of the water content optimun shown in Figure 4 below

Figure 4 shows the maximum value of water content optimun of $10 \%$ occurred on the addition of waste chicken egg shell on curing 21 days and the addition of up to $14 \%$ showed a decline of $22,18 \%$ be $20,10 \%$.

\section{Conclusion}

Results of research on soils is added to the waste chiken eggs shell as follows:

Soil sample from district Gowa, Sungguminasa, Subdistrict Pallangga, Poros Limbung street in South Sulawesi Province is classification by USCS is the types of silt organic and clay organic with low plasticity (OL).

Unit weight dry value in the addition of $10 \%$ waste chicken egg shell has increased a maximum of $1.58 \mathrm{gr} / \mathrm{cm}^{3}$ into $1,630 \mathrm{gr} / \mathrm{cm}^{3}$ at 14 days of aging (increase occurred at $3,164 \%)$

Water Content Optimun in the addition of $10 \%$ waste chicken egg shell has increased a maximum of $22,18 \%$ into $20,33 \%$ at 21 days of aging (decrease occurred at 1,85\%)

\section{Acknowledgment}

The author wish to express their gratitude and deep appreciation to Gladys Gabriella Tecoalu Faculty of Engineering Study Program Civil Engineering for their assistance and help.

This research was supported by Universitas Atmajaya Makassar, South Sulawesi. The author are grateful to the authorities for their support.

\section{References}

1. Hardiyatmo, Hary Christady. Treatment of Landslide and Erosi.Gadjah Mada University Press. Yogyakarta, 2006

2. P. Beukering, M. Schaafsma, A. Usup, and M. Embang, 2009, The Economic Value Peatlands in Central Kalimantan: Public Perception Of Rehabilitation and Revitalization Ex PLG Central Kalimantan, 2009

3. T. Yuwanta, Eggs and quality egg. Gadjah Mada University Press, Yogyakarta, 2010

4. T. O. Soine, \& Wilson, C. O. Roger's Inorganic Pharmaceutical Chemistry.Seventh Edition. Philadelphia: Lea \& Febiger. Pages. 390, 391.,1961

5. Ditjen POM, Kalsium Dalam Cangkang Telur, Ditjen POM Press, Jakarta, 1995

6. Nurul Gofar, Khairul Annar Kassim," Introduction to Geotechnical Engineering" Prentice Hall, Pearson Education South Asia Pte, Ltd, Singapore, 2007

7. E. Bowles, Joseph, Physical and Geotechnical Properties of Soils, Second Edition, McGraw-Hill Book Company, 1985

8. A. Cassagrande, "Research on the Atteberg Limitsof Soils," ASCE J. Geotech. Eng. Div. Vol 90, Sept 1964

9. F. Craig, S. Robert, Budi Susilo, Soil Mechanics, Fourth Edition, Erland., 1987 